\title{
GESCHIEDENIS VAN DE NEDERLANDSCHE BOVENWINDSCHE EILANDEN IM DE 18DE EEUW
}

\author{
DOOR
}

PROF. DR. L. KNAPPERT

\section{HOOFDSTUK VI (Vervolg)}

$\S 15$. Ook de Deensche regeering had, gelijk wij zagen, een oorlogsschip uitgerust, om op St. Thomas den handel met vreemde natiën te verhinderen ${ }^{1}$ ). Maar zij was te zwak om dat, gelijk Engelschen, Franschen en Spanjaarden, te kunnen doen, zwakker nog dan wij. Bovendien zouden de bewoners van St. Thomas, meest van Nederlandsche afstamming (er waren geen honderd Denen) naar het verbod toch niet geluisterd hebben ${ }^{2}$ ). Er was trouwens in deze jaren weinig handel op de Deensche eilanden, zooveel te meer met de Fransche koloniën, die ons gedurende den oorlog vrije vaart lieten. En aldus kon men aanschouwen, dat Engelsche schepen uit N.-Amerika en Engelsche en Nederlandsche schepen uit Ierland provisie aanbrachten en Statiaansche ze daarna verder naar de Fransche eilanden voerden. In 1745 waren het er een veertig en de Engelschen, jaloersch op deze onze wél-vaart, namen er in dat jaar negen van weg, onder voorwendsel dat ze krijgsbehoeften verscheepten. De commandant van 's Konings vloot op Antigua, Warrin, protesteerde tegen het zenden zelfs van levensmiddelen, omdat daardoor de honger de Franschen niet tot overgave dwong, en hij herinnerde er ons aan, dat hij Martinique en Guadeloupe blokkeerde en alle schepen zou nemen, die de blokkade braken. Waartegen wij inbrachten, dat de Franschen zelven kost genoeg hadden, dat er nooit oorlogscontrabande werd uitgevoerd en dat wij van die blokkade niets hadden bespeurd, vermits er geregeld verkeer was ${ }^{3}$ ). Kon de prijsrechter op Antigua niets

1) Boven $\S 3$.

2) Joh. Heyliger Pzn. aan X 5 Dec. 1745, port. no. 6, fol. 539 r.

3) Warrin aan Heyliger 28 Jan. 1744 en Heyliger aan Warrin 15 Febr. 1744, port. no. 6 , fol. 545,546 . 
kwaads vinden, dan deed hij onderzoek naar de reeders en, al hadden zij 20 jaar op St. Eustatius gewoond maar waren op Engelsch gebied geboren, dan veroordeelde hij hen toch, nademaal een geboren Engelschman immers nooit en nergens onderdaan van een vreemden prins kon zijn ${ }^{1}$ ). Die rechter van het admiraliteitshof op Antigua heette bovendien van rechten niets te weten, maar wat de fiscaal eischte dat was zijn vonnis. Zoo betaalden wij meest het gelag, gelijk wij het in het bovenvermelde geval van schipper Houwel den Franschen hadden gedaan ${ }^{2}$ ). De commandeur zond ook thans weder (met een bark, tot de huur waarvan de kooplieden op St. Eustatius, bij wijze van voorschot aan de Comp., hadden bijgedragen, want eene eigen bark hield de Comp. er niet op na!) twee bemiddelaars naar admiraal Townsend, generaal Matthew en rechter Benjamin King, maar zonder gevolg ${ }^{3}$ ).

$\S 16$. Ter verdediging van hunne rechten legden alle koopmanshuizen op St. Eustatius eene verklaring af dat niemand ooit contrabande had vervoerd, behalve dan Louis Puech die voor eigen gebruik een zadel met tuig naar Grande Terra had meêgenomen; Jan Philips die in 1745 voor rekening van Jean Bignon 2000 pond buskruit van Guadeloupe had verscheept; en Jozef Lindesay een degen. Ja, de commandeur legde een uittreksel over uit al de manifesten der goederen, sedert de oorlogsverklaring tusschen Engeland en Frankrijk door onze kooplieden afgescheept en geladen, om te negotieeren op de Fransche eilanden van 4 Januari 1745 tot 31 December $1746^{4}$ ).

Geen wonder, dat Heyliger telkens aandrong op een paar oorlogsschepen ter beveiliging van den handel, doch dan met opzettelijke orders om te kruisen. Hij doelde daarbij op het kort te voren gebeurde met 's Lands oorlogsschip 't Hof van St. Janskerk van de admiraliteit van de Maze, kapitein Jacob Edward van der Gon. Deze held, van Curaçao naar St. Eustatius zeilende, ontmoette ter hoogte van Porto Rico twee Engelsche kapers van Antigua, kapiteins Setplace en Higgons, en liet aanstonds de witte vlag waaien. De eerste officier Brahé voer met 8 man aan boord van een der kapers, waar men hem gevangen hield! Wanneer zoo iets met een oorlogsschip kon gebeuren - wat mocht men van een

1) Aldus o.a. met de sloep Amitié van John Pyter en de Elisabeth van Michouw, beiden bewoners van St. E., Heyliger aan Matthew 6 Aug. 1745, port, no. 6, fol. 547.

2) Boven $\S 3$.

s) Joh. Heyliger aan X 5 Dec. 1745 , port. no. 6, fol. 540 r. -541 r. Verklaring der kooplieden op St. E. d.d. 18 Nov. 1745 aldaar, fol. 553 r.

4) Verklaring der koopmanshuizen d.d. 16 Dec. 1746, port. no. 6, fol. 838 v. Extract aldaar, fol. 842 r. $-885 \mathrm{v}$. 
koopvaarder verwachten? Welnu, deze Van der Gon had beweerd, dat hij niet in de West was gekomen, om te kruisen ${ }^{\mathbf{1}}$ ).

Wij zaten voortdurend tusschen hamer en aambeeld. Ik heb boven verhaald van de klachten van den Franschen gezant De St. Contest over onze hulp aan Engelschen op St. Maarten $\left.{ }^{2}\right)$. Thans antwoordde de vice-commandeur Abr. Heyliger Pzn. dat wij juist Fransche onderdanen geherbergd en daarna voortgeholpen hadden naar St. Kruis, Guadeloupe, St. Vincent, wat ons op groote onaangenaamheden met de Engelschen was te staan gekomen. De markies De Caylus en de sieur Point Sablé hadden dat wel geweten, maar waren beiden overleden ${ }^{3}$ ). Wie zich herinnert wat wij over het gedrag der Engelschen op St. Maarten hebben verhaald, begrijpt gereedelijk, dat wij geen brandenden lust hadden hen ter wille te zijn.

$\S 17$. Het garnizoen op St. Eustatius van 50 man ${ }^{4}$ ) had de dood tot op 43 verminderd. Om het dreigend oorlogsgevaar vroeg de commandeur dringend om aanvulling, maar onder hen geen Franschen, ,welke natie ons niet dienstig is”. De Engelsche ook niet, zou men zeggen, maar die bood zich ook veel minder aan. Meteen vroeg de Raad 20 stukken kanon, 10 achttien- en 10 twaalfponders met toebehooren ${ }^{5}$ ). Wederom haastten de Heeren zich niet; in Maart 1748 was er geen antwoord en geen geschut, terwijl de oude kanonnen sprongen bij het gebruik of niet ver genoeg droegen om te verhinderen, dat Fransche kapers een bark van Saba namen ter reede van St. Eustatius! Deze laksheid van Bewindhebberen viel te ernstiger te betreuren, omdat de burgerij thans voor de verdediging des eilands alles wilde doen. Nu besloten zij zichzelven te helpen en brachten een bedrag bijéén voor fortenbouw. Eén, Hollandia, zou bij het ons reeds bekende machenille-

1) Heyliger aan X 18 Juni 1746, aldaar fol. 648, 649. Deze Jacob Edward van der Gon was de oudere broeder van Adriaan David, den lateren schout bij nacht, die als kapitein in 1755 het bevel voerde ook over 't Hof van St. Janskerk 36 st. in het eskader van schout-bij-nacht Boudaan, De Jonge, Geschied. Ned. Zeewezen IV, 308, noot, 361. Hij was ged. te Schiedam 19 Maart 1717 en overleed te Bergen op Zoom 18 Juni 1792. Onze Jacob Edward, ged. te Schiedam 26 Juli 1713, overleed aldaar, ongehuwd, 23 Sept. 1746, dus kort na zijne oneervolle capitulatie. Beiden waren zonen van Jacob van der Gon, 1663-1729, kapitein met den breeden wimpel of brigadier ter zee, ook ter admiraliteit van de Maze en van Jeannette Tenwiek. Volgens vriend. mededeeling van Dr. Th. R. Valck Lucassen te Driebergen, een nazaat van Adriaen David, die de geschilderde portretten van hem en van Jacob bezit.

2) Boven $\$ 3$ in fine.

3) Abr. Heyliger Pzn. aan X 29 Juni 1751, port. no. 7, fol. 401, 402.

4) Boven $\S 4$ in fine.

5) Comm. en Raden aan X 6 Juli 1747, port. no. 7, fol. 15. Heyliger aan X 8 Juli 1747 aldaar fol. 17. Boek 3, fol. 696. Monsterrol van het garnizoen 29 Oct. 1746, port. no. 7 , fol. 19 . 


\section{NEDERLANDSCHE BOVENWINDSCHE EILANDEN}

boschje komen, beneden het nieuwe fort, waar de hevigste stoot des vijands te vreezen was. Dan een fort op Hellgat's punt beoosten fort Dollijn, vanwaar uit men de schepen aan de Zuidzijde kon beschieten. De Raad dacht ook nog over een fort boven op een berg, vanwaar uit men, over fort Oranje, het dorp en de reede zou bestrijken. Den bouw van al deze forten zouden de burgers vrijwillig bekostigen, wanneer dan - billijk verzoek - de Heeren voor de bewapening wilden zorg dragen, voor Hollandia 8 tienponders, 8 vier en twintigponders, voor Zeelandia 8 vier en twintigponders, voor het fort op den berg, dat Nassau zou heeten, waren 20 twaalfponders noodig. In fort Sommelsdijk was het geschut zeer slecht, waarom men uit de reeds ingezamelde penningen op St. Christoffel alvast 8 zesponders had gekocht. Wanneer nu de Heeren ook eens over de brug wilden komen! Heyliger, goed van vertrouwen, verwachtte hun zending zelfs onder konvooi ${ }^{\mathbf{1}}$ ).

Inderdaad hadden de burgers gehoor gegeven aan eene oproeping, waarin de regeering, gelet op den ,florissanten en bloeyenden staat van dit eylandt door des Heeren zegen en goedheidt, die in oorlog ten eenemale zou geruineert zijn", aan de goede, welmeenende, liberale patriotten had gevraagd om vrij en mildelijk voor het welzijn des vaderlands te geven. Van de ingeschreven som, die in de raadskamer moest worden ingebracht, zou men 10\% aanstonds, de rest in termijnen storten. Wie niet teekenden zouden Comm. en Raden naar rato der vrijwillige giften aanslaan. Op de lijsten komen voor: Commandeur Heyliger met 1000, Pieter Heyliger en Simon de Graaf ieder met 500, de andere raadsleden Jasper Ellis en Joh. Markoe ieder met 200, Jan de Windt met 250 pesos. Er waren ook giften van 20, 10 en 5 pesos. Onze oude kennis, de wed. Kowan ${ }^{2}$ ), gaf 25. Het geheele bedrag was 9217-5-0 ${ }^{3}$ ).

Men zou verwacht hebben, dat de Heeren, dit bewijs van burgerdeugd hoogelijk prijzend, voor 't minst thans zouden geantwoord hebben. Maar in Juni 1748 was er noch bericht noch geschut. Commandeur Heyliger, zelf een welmeenend man, vermoedde dat hun brieven zich wel in de schepen van Corn. Sybrants van Amsterdam en Robert Numan van Rotterdam zouden bevonden hebben, beide immers door Fransche kapers genomen en naar Gua-

1) Comm. en Raden aan X 23 Maart 1748, boek 3, fol. 703, 704 r.

2) Juist in dezen tijd ging zij al maar door met drensen om haars mans achterstallig rantsoen en zond nog eens een rekest in, 22 Nov. 1748: „Suppliantesse Anna Oyen, wed. ds. Anthony Kowan" enz., met de volgende rekening: 26 jaren rantsoen, berekend op 16 \& gezouten vleesch per week maakt 21632, idem brood 16224, idem gort $10816 \mathscr{Z}$, port. no. 7 fol. 225,226 . Wij zagen vroeger dat zij in 1744 stond aangeslagen voor 5. 4. 8. 7 slaven.

3) Boek 3, fol. 705-708 r. 
deloupe opgebracht. In zulk een geval liet men den brievenzak ook wel met een zwaren steen in zee zinken, zooals schipper Klaas Wagenaar van de Jonge Jan had gedaan, toen een Fransche kaper hem bij Martinique nam.

$\S 18$. Ook in ander opzicht had het uitblijven van alle bericht den commandeur in groote moeilijkheden gebracht, in de onzekerheid nl. of de vaderlandsche kaperbrieven ook voor deze eilanden golden? Totdat directeur Faesch van Curaçao hem had bericht, dat H.H. Mog. order tot retorsie tegen den koning van Frankrijk in de West-Indiën gegeven hadden, tot bestrijding dus van den vijand met zijn eigen wapenen. In Curaçao had men al aanstonds drie Fransche kapers met slaven genomen. Toen besloot Heyliger, terwijl door dat uitblijven van tijdig advies 22 zijner eigen schepen in de Fransche havens wel verloren zouden zijn, met zijne geringe middelen toch iets te doen. Hij gaf kaperbrieven aan de Prins van Oranje, een klein „bootie” van twee stukken kanon! Natuurlijk hadden de Franschen het aanstonds opgebracht. Enkele kooplieden rustten toen de bark Nassau uit, voerende 8 drieponders en 16 staartstukken ${ }^{1}$ ) benevens 65 man, en eveneens de brigantijn De Zeven Provinciën, kapitein Alex. Ratter met 140 man, 14 zesponders en 20 staartstukken. De Nassau veroverde reeds aanstonds het schip Le Fagon kapitein Lanioux, op weg van Martinique naar Bordeaux, met 187 vaten poedersuiker, 19000 pond koffie en 3000 pond cassia ${ }^{2}$ ). De Zeven Provinciën had tusschen Sint Maarten en Sint Bartelmees (St. Barthélemy) een commissievaartuig van Martinique veroverd en naar St. Eustatius opgebracht. Heyliger (altijd nog zonder bericht van de Heeren) had uit nieuwspapieren gelezen, dat H.H. Mog. premiën voor veroverde Fransche schepen hadden uitgeloofd en zou gaarne willen weten, of die plakkaten ook voor zijne eilanden golden? Daar hij nooit bericht kreeg ('s mans eigen smartelijke woorden) wist hij nimmer, waaraan hij zich te houden had.

Was het zware geschut er nu maar geweest! Fort Hollandia was gereed, maar zonder kanonnen kon het immers de schepen ter reede toch niet tegen de kapers beschermen? En waren de oorlogsschepen er maar geweest! Want nu moest men (o, bittere smaad) wachten op het believen van den Engelschen admiraal, of die ook onze koopvaarders wel zou willen convoyeeren. Het was hem vóór twee maanden al gevraagd, maar hij had nog niet geantwoord ${ }^{3}$ ).

1) Woordenboek XV $207 a$ : ,zeker soort van ouderwetsch stuk geschut”.

${ }^{2}$ ) Cassia fistula. De vruchten met mais in water gekookt geven een laxeerenden drank, Oldendorp, $a$. $w$. I $192 f$.

3) Heyliger aan X, 27 Juni 1748, boek 3, fol. 709 r.-710 v. Port. no. 7, fol. 96 v, 


\section{NEDERLANDSCHE BOVENWINDSCHE EILANDEN}

Eindelijk, 27 Juni 1749, kwamen er drie schepen uit patria, de Publicola kapitein Jan de Kock, de Erfprins kapitein van der Schaaff en de Leonidas. Zij brachten copie van het vredestractaat van Aken (de vrede was 18 October 1748 geteekend), militairen die men naar St. Maarten doorzond ${ }^{1}$ ) èn .... de lang verwachte kanonnen, 5 achttien- en 5 twaalfponders. Wanneer nu, juichten onze eilanders, van St. Kruis het hout voor de affuiten zou gekomen zijn, kon men het geschut plaatsen op het nieuwe fort Hollandia. Helaas, met die vreugde was het spoedig gedaan! De wijze en voorzienige Heeren hadden alle kogels vergeten ${ }^{2}$ ). Verzuimd Braziel, verzuimd Nieuw-Nederland èn Berbice èn Ceylon èn Formosa. Deze bladzijden spreken wel zeer nadrukkelijk ook van verzuimd Eustatius.

$\S 19$. Wat wij over de langzame correspondentie der Heeren te berde brachten moeten wij thans nog aanvullen door de vraag te beantwoorden, hoeveel tijd het nieuws van vaderlandsche gebeurtenissen noodig had om onze eilanden te bereiken en hoe men er daar op reageerde? In Augustus 1747 wist men noch op St. Eustatius noch op St. Maarten iets officieels van de inhuldiging van Prins Willem IV op den 10den Mei van dat jaar, zoodat Heyliger vroeg „of hij daaraan ook iets doen moest" 3)? Eind December 1747 wist men op het eiland, dat de Franschen Bergen op Zoom, Steenbergen en Lilloo genomen hadden, ,zoodat de oorlog nu wel zou uitbarsten; jammer van dit bloeiende eiland" " $)$. Inderdaad was Löwenthall 18 April 1747 in Staats Vlaanderen gevallen, had zonder slag of stoot alle plaatsen genomen, zelfs het sterke Axel, dat zich op de eerste uitnoodiging over gaf, terwijl Bergen op Zoom 16 September bij verrassing overging ${ }^{5}$ ). Het bericht van den inval in Zeeuwsch Vlaanderen had er dus acht maanden, dat van het verlies van Bergen drie maanden over gedaan.

Vrij wat langzamer verliep de geschiedenis van de Liberale gift. Men herinnert zich, dat de Staten van Holland 12 September 1747 deze Milde gift hadden uitgeschreven, eene vrijwillige leening, $2 \%$ van bezitters van $f 2000$ of daarboven, $1 \%$ van die van $f 1000$ tot $f 2000$, van hen die minder dan $f 1000$ bezaten zooveel als zij zouden goedvinden, mits zij althans iets inbrachten. Den 10den October 1749 besloot men de inteekening ook voor O. en W.-Indië open

1) Het waren er zes, van wie één bij aankomst overleed, natuurlijk door de ellende der reis, Abr. Heyliger Pzn. aan X 12 Aug. 1749, boek 4, fol. 4.

$\left.{ }^{2}\right)$ Heyliger aan X 27 Juni 1749, 16 Juli 1750, port. no. 7, fol. 252, 253, 339.

3) Heyliger aan X 14 Aug. 1747, boek 3, fol. 698 r. De Wever aan X d.d. St. M. 20 Juli 1747, port. no. 7, fol. 38 r.

4) Heyliger aan X 22 Dec. 1747, port. 7, fol. 84 .

5) Blok, Geschied.III 434, 436 vlg. 
te stellen ${ }^{1}$ ). Weder twee jaren later vroeg toen Kamer Amsterdam aan Heyliger eerst nog advies, „op wat wijze de Liberale gift gevoegelijk in zijne kolonie zou kunnen worden geïntroduceerd ?" ${ }^{2}$ ) Commandeur en Raden gaven daarop dit merkwaardig antwoord, al te zeer in mineur naast hunne verzekeringen elders van den bloei der kolonie. St. Eustatius, zeiden zij, was sedert lang in zeer declineerenden staat door slechte negotie en droogte, nauwelijks konden de inwoners met hunne menigvuldige kinderen leven, terwijl de kooplieden groote schade leden door de lage prijzen in Europa. Het was waar, dat de burgers vrijwillig de versterking des eilands op zich genomen hadden, maar zij hadden daaraan eigenlijk veel meer bijgedragen dan hun vermogen hun vergunde, omdat zij nog met huivering dachten aan de plundering door Cassart in 1713 en de herhaling daarvan duchtten. Saba was klein en „armtierig”, de menschen waren daar schildpadvisschers aan de Zuidbaaien en verkochten dan hun vangst op de Engelsche eilanden. Landbouw dreef men daar niet. St. Maarten was mede zeer arm door droogte. Had men niet wat zout uit de pannen vergaderd, dan had men slaven moeten verkoopen, ofschoon slaven (wij herinneren ons de uitdrukking) ieders voornaamste middel van bestaan uitmaakten. Derhalve mochten H.H. Mog. hen ontheffen van alle verdere belasting. Ging dat niet, ja, dan moest men de ongelukkige burgerij maar taxeeren, hen die geen geld hadden maar dwingen hun slaven en bestiaal te verkoopen en dan zouden zij wel in menigte op de andere eilanden gaan wonen ${ }^{3}$ ). Ziedaar het niet juist aanmoedigend advies.

Eind November 1748 ontving Heyliger copie van „het 16de artikel van de praeliminairen op de vredesconferentie te Aken, rakende het casseeren der hostiliteyten en van de acte van suspensie van wapenen tusschen Vranckrijck en Engelant d.d. Parijs 19 Augustus 1712"'. Deze voorafgaande punten hadden Frankrijk, Engeland en de Staten des nachts na den 30sten van Grasmaand 1748 geteekend. De stilstand van wapenen zou te lande beginnen zes weken na de teekening van dit verdrag, en ter zee gelijk bij het verdrag van wapenschorsing tusschen Frankrijk en Engeland in 1712 geregeld was $\left.{ }^{4}\right)$. Dat de vrede zelf van Aken, 18 October

\footnotetext{
$\left.{ }^{1}\right)$ Wagenaar $a \cdot w \cdot \mathrm{XX} 161$.

) Kamer Amst. aan Heyliger 27 April 1751, 342 W. I. C. 475.

3) Boek 4, fol. 178-182. Abr. Heyliger Pzn. klaagt 1 Juli 1752 over de droogte op St. M., ruineus voor de opgezetenen, zoodat „de Almachtige God zijne castijdende Handt haastelijck moge inhouden", boek 4, fol. 279.

4) Comm en Raden aan X 30 Nov. 1748, port. no. 7, fol. 223 v. Wagenaar a. w. XX $182-188$.
} 


\section{NEDERLANDSCHE BOVENWINDSCHE EILANDEN}

1748, 27 Juni 1749 op onze eilanden bekend was, hebben wij gezien.

Den 24sten Maart 1749 was de Prins opperdirecteur der O. I. Compagnie geworden, iets later ook van de W. I. C., met als representanten Jan van Marcelis en Thomas Hope ${ }^{1}$ ). Heyliger berichtte 27 Februari 1751 dat hij tijding van deze electie van Z.D.H. ontvangen had ${ }^{2}$ ), maar 22 Juli 1750 wist men het althans op St. Maarten ${ }^{3}$ ) en 30 December 1750 richtten kooplieden op St. Eustatius zich tot Hope als representant ${ }^{4}$ ).

$\S 20$. De Fransche koning had paspoorten voor Nederlandsche schepen gegeven, zoodat ook die van onze eilanden veilig naar Fransche havens komen konden. De markies de Caylus zond met dit bericht den sieur Regnault op de Elisabeth, met de opdracht om meteen te onderhandelen over de terugzending van de bemanning van een Fransch schip, dat een Engelsche kaper genomen en naar St. Eustatius gebracht had, eene daad die hij als onvriendelijk beschouwen moest ${ }^{5}$ ). Het bleek, dat er in het geheel geene bemanning was aangebracht, zoodat Heyliger ook niemand kon terugzenden, iets wat hij anders altijd deed. Daarom griefde het hem op zijn beurt, dat de sieur St. Rémis bij afwezigheid van den gouverneur van Guadeloupe, De Clieux, de bemanning van een Hollandschen kaper gevangen hield, ja enkelen hunner naar Frankrijk en wel heel naar Marseille, zóó ver van huis, gezonden had. Hij vaardigde daarom op de Phoenix den heer Doncker af met een vlaggetroes ${ }^{6}$ ) om deze zaak te regelen en schreef meteen aan gouverneur De Clieux, dat zoo híj op het eiland geweest ware, hij zeker niet zoo zou gehandeld hebben en dat hij thans stellig aan Mons. St. Rémis zijn ongelijk zou aantoonen en de gevangenen met Doncker terugzenden. Het viel ten slotte nog mede, drie man waren er naar Frankrijk gezonden, de anderen met een vlaggetroes naar Antigua ${ }^{7}$ ).

\footnotetext{
1) Wagenaar $a . w . \mathrm{XX}, 332$ vlgg.

2) Port. no. 7, fol. 356.

s) Volgens deze lakonieke aanteekening: „De bijlagen tot de missive van Abr. Heyliger Pzn. van dato St. Maarten 22 Juli 1750 zijn ten huyse van den Heer Representant Hope", boek 4, ongedat., ongepag. na folio 76.

4) Boek 4, fol. 82 .

s) Markies de Caylus aan Heyliger d.d. Martinique 20 Mei 1748, copie, boek 3 fol. $711 \mathrm{r}$.

$\left.{ }^{6}\right)$ Vlaggetroes, flag of truce, parlementaire vlag. Iemand met een flag o' truce dus als onderhandelaar zenden. Verg. Prick van Wely, Engelsch Woordenboek op parlementair. Vriendelijke mededeeling van Dr. A. Beets.

$\left.{ }^{2}\right)$ Heyliger aan De Caylus 30 Mei 1748, copie, Fransch, boek 3, fol. 712 r. Dez. aan De Clieux zelf. dat., copie, Fransch, aldaar fol. 713 r. Heyliger aan X 27 Juni 1748, aldaar fol. $710 \mathrm{r}$.
} 
Tegelijkertijd beklaagde zich de nieuwe Engelsche gezant bij de Staten, Dayrolles ${ }^{1}$ ), dat de deserteurs van het regiment van kolonel D'Alzell op St. Christoffel zich op St. Eustatius schuil hielden en daar bescherming genoten. H.H. Mog. vroegen inlichting en Heyliger antwoordde dat de officieren hun kolonel misleidden. Eigenlijke deserteurs liet Heyliger altijd vastzetten, waarom zij ook zijn eiland wijselijk vermeden. Maar de officieren op St. Christoffel stonden aan hun soldaten geregeld toe, om op daggeld te gaan werken waar zij wilden en wisten dan soms in weken niet, waar zulke menschen zich ophielden. Heyliger vond dat hij, alleen omdat de Engelschen spijtig waren over onze welvaart door den Franschen handel, hun niet het genoegen behoefde te doen van die dusgenoemde deserteurs te weren. Ach ja, die stijgende welvaart, hoe verheugend ook, vervulde hem met zorg. Hoe treffen ons zijne smeekbeden: „Ik zou toch nog eens willen bidden dat U.E.Gr.A. in consideratie zoudt willen nemen, dat een land niet met eere kan gedefendeerd worden als men het noodige niet heeft. Het zoude voor mij chagrinant zijn te zien, een land dat gedurende zoo weinig tijd zoo considerabel is geworden weer al zoo haast tot niets te zien loopen daar het nog vóór te komen zou zijn" $\left.{ }^{2}\right)$. Inderdaad treffende woorden - behalve voor de Heeren. Het diepe verval dat in de Republiek ging intreden vertoont zich het akeligst in de koloniale verwaarloozing en in die der vloot.

$\S 21$. Wij moeten thans tot enkele binnenlandsche aangelegenheden der kolonie terugkeeren. De secretaris Jan de Windt kon het met den commandeur niet goed vinden, die reeds kort na zijne ambtsaanvaarding weigerde hem de papieren der secretarie over te geven, terwijl die van wijlen secretaris Spieringh, ofschoon opgevraagd, zich nog onder de weduwe bevonden. Men mompelde, dat daaronder ook de ons bekende schuldbrieven van ingezetenen aan de Compagnie wegens gekochte slaven weggeborgen lagen ${ }^{3}$ ). Ook wilde Heyliger hem niet als raadslid erkennen en zijn ,woelende en toomelooze haat" uitte zich in „choquante en piquante expressies". Volgens den secretaris had al te overvloedige ambitie den commandeur zóó buitensporig gemaakt, dat hij niet de minste inmenging dulden kon en dan aanstonds souvereine authoriteit

\footnotetext{
$\left.{ }^{1}\right) \mathrm{Hij}$ was de vertrouwde van Lord Chesterfield, die juist in 1747 staatssecretaris geworden en voorstander van den vrede was.

$\left.{ }^{2}\right)$ Heyliger aan X 22 Maart 1748, port. no. 7, fol. 97.

3) Jan de Windt aan X, 4 Juli 1744, port. no. 6, fol. 201 r. Copie verzoekschrift van De Windt aan Heyliger d.d. 10 April 1744 dat de raad mej. Susanna Sotuyn (sic. Sautijn) wed. Pieter Carel Spieringh moge „constrengeeren” de compagniespapieren af te geven, port. no. 6, fol. 202 r.
}

West-Indische Gids XIII 


\section{NEDERLANDSCHE BOVENWINDSCHE EILANDEN}

toonde. „Ick verstaan niet dat gij een woordt sult spreeken, gij zit daar maar om de pen te voeren; soo gij durft spreeken sal ick andere mesures met u nemen". Een koopman, vond De Windt, zou zijn minsten klerk zoo niet behandelen; voor hem, op zijne jaren, waren zulke ,affrontelijke” woorden onverdragelijk. Eens zelfs was de commandeur met zijn rotting in de hand "passieuselijcken” op hem aangedrongen, zeggende: „Karel, gij zult niet spreecken, ick ordonneer u u aanstonds neer te zetten". Mogen wij De Windt gelooven, dan was de commandeur ook in den handel niet zuiver. Althans, toen den 14den September 1744 de jonge Jan de Windt, luitenant der burgerij en koopman, van een NewYorkschen schipper zijne gansche lading meel gekocht had, verbood Heyliger op 300 pesos boete den man de lossing, vóór hij 80 van de beste en zwaarste vaten uit de lading genomen had. Geen koopman mocht negotie doen vóór hij aan $Z$.Exc. de voorkeur geboden had. Ja, men fluisterde, dat er vaak 's nachts diepgeladen vaartuigen aankwamen, die losten, zonder dat men kon bespeuren waar de goederen bleven ${ }^{1}$ ).

Bewindhebberen gelastten hem 2 October 1744 dat hij den commandeur de uitlevering der papieren afeischen zou, hij deed het 1 Februari 1744 en 19 Maart had zij plaats. Maar van de papieren van Spieringh zeide Z.Exc. niets te weten, ofschoon De Windt hem verzekerde, dat ze bij de weduwe in een kistje en in een flesschenkelder ingepakt lagen. De weduwe op haar beurt wilde onder eede verklaren, dat zij geen origineele stukken bezat, waarop de commandeur verder vragen verbood. Een der raadsleden vertelde aan De Windt ,onder secretesse” dat Mej. Spieringh op goed vertrouwen de stukken aan Heyliger had ,getransporteert" en zich dat nu onder tranen beklaagde ${ }^{2}$ ).

$\S 22$. In deze pijnlijke verhouding tusschen twee op elkander ąangewezen hooge ambtenaren bracht de dood ook thans de oplossing: den 6den Augustus 1747 overleed, 52 jaar oud, de secretaris-vendumeester, dien wij op zijn levensweg zoo lang gevolgd hebben ${ }^{3}$ ). De commandeur stelde a.i. Jan Gottlieb Frederic aan. Sollicitanten naar het thans belangrijk ambt waren er genoeg. Abr. Doncker vroeg met de parmantige verzekering, dat hij de gansche wereld dagvaardde om iets tot zijn nadeel in te brengen. Ook Heyliger oordeelde gunstig over den toen 26 jarigen man als zeer be-

\footnotetext{
1) Jan de Windt aan X 21 Nov. 1744 , port. no. 6 , fol. 310 r. -312 v.

2) Jan de Windt aan X 5 April 1745, port. no. 6, fol. 459 r. -460 v.

s) Heyliger aan X 10 Aug. 1747, port. no. 7, fol. 60 r. Resolutiën van X, Lunae 13 Oct. 1749 , fol. 135 r.
} 
kwaam, onbesproken van gedrag en bovendien kleinzoon van twee commandeurs, Doncker en Salomonsz ${ }^{1}$ ). Paul Amyot vroeg ${ }^{2}$ ). Frederic vroeg als ,een oude compagniesdienaer" ${ }^{3}$ ). Albert van Heyningen vroeg met de belofte zich als een vroom en eerlijk persoon te zullen gedragen; de tweede maal met de bijvoeging dat hij op St. Maarten ,immolimenten”, tractement noch vrije woning had, waarmede een man toch zijn fatsoen moest "mintineeren”, juist wat wij Abr. Heyliger Pzn. ook hoorden zeggen ${ }^{4}$ ). De Heeren sloegen er geen acht op en benoemden Jan de Graaf, die zoo spoedig mogelijk uit Holland vertrekken zou. Hij kwam en werd 15 Juli 1751 geïnstalleerd ${ }^{5}$ ).

Nicolaas Heyliger Jansz. had bij het overlijden zijns vaders, commandeur Joh. Heyliger den oude, gevraagd om continuatie als waagmeester, vermits de inkomsten dier betrekking het steunsel en onderhoud der weduwe en nagelaten kinderen uitmaakten. Sinds had hij met eere gediend onder Faesch, Coesvelt, Ellis en den tegenwoordigen commandeur. Thans, 1750, liep er een gerucht, dat de Heeren hem wilden ontslaan, weshalve hij om bestendiging vroeg $\left.{ }^{6}\right)$. Hij voegde er een gunstig getuigschrift bij voor hem als waagmeester en ,roeyer”, geteekend door Comm. en Raden, voorzien van een papieren, als ster uitgeknipt, zegel der Comp. vertoonend de letters GWC ${ }^{7}$ ). Ook de kooplieden van St. Eustatius kwamen bij den representant van Z.D.H. en bij Bewindhebberen voor hem op. Zij zouden zijn ontslag zeer bejammeren daar hij bekwaam, ijverig en van onbesproken gedrag was en zij hem niet gaarne zouden missen. Dit rekest teekenden 116 kooplieden, op de beteekenis van welk getal wij reeds wezen $\left.{ }^{8}\right)$. De commandeur zelf prees hem als vigilant, maar zonder middelen, met eene ,swaare en deugdsame familie”, onder wie zijne hoogbejaarde moeder, weduwe van Comm. Heyliger. Hij verzocht ernstig den

1) Abr. Doncker aan X, 18 Aug. 1747, port. 7, fol. 62. Heyliger aan X, 14 Aug. 1747, boek 3, fol. $699 \mathrm{v}$.

$\left.{ }^{2}\right)$ Amyot aan X 8 Aug. 1747, port. no. 7 (eerst op) fol. 273.

$\left.{ }^{3}\right)$ Frederic aan X 26 Aug, 1747, aldaar fol. 68 .

4) Alb. van Heyningen aan X, 5 Jan. 1748, boek 3, fol. 700-701 r. 26 Febr. 1749 aldaar fol. 748. 12 Aug. 1749 boek4, fol. 70 . Boven $\$ 6$ in fine.

$\left.{ }^{5}\right)$ Missiven van X 15 Aug. 1750 aan Joh. Heyliger Pzn. Kam. Amst. aan idem, 1 Mei 1751. Comm. en Raden aan X, 27 Febr. 1751, boek 4, fol. 87. Heyliger aan X, 13 Juli 1751 , port. no. 7 , fol. 427 .

6) Nic. Heyliger Jansz. aan X, 24 Dec. 1750, boek 4, fol. 77-79.

${ }^{7}$ ) Idem aan X 7 Jan. 1751, boek 4, fol. 81. De initialen GWc, Geoctrooieerde W.I. Comp. kwam ik hier voor 't eerst in de stukken tegen. „, Roeyer”, hij die met eene roede de hoogte van den wijn in het vat meet.

${ }^{8}$ ) Kooplieden van St. E. aan X, 30 Dec. 1750, boek 4, fol. 82-86. Boven § 9. 
man te herbenoemen ${ }^{1}$ ). Deze maal luisterde men in Amsterdam en liet hem zijn post behouden ${ }^{2}$ ).

Wij hebben vroeger bij de zaak van Corn. Leever gezegd, dat Heyliger in 1747 voor niet langer dan een jaar verlof kreeg om naar Suriname te gaan ${ }^{3}$ ). Jasper Ellis zou hem zoo lang vervangen en had beloofd zijn plicht te doen. Hij schreef dit nog 15 November 1747 en meldde toen meteen, dat er 30 September in een orkaan dertig Nederlandsche schepen en even zooveel barken van het eiland vergaan waren ${ }^{4}$ ). Heyliger schreef ook over dien storm in een brief van 22 December 1747 en dat hij nieuwe schepen koopen zou uit die 28 Fransche, die, voor Martinique bestemd, door de Engelschen naar Antigua, St. Christoffel en Montserrat waren opgebracht. Zoo was des eenen dood des anderen brood. Intusschen blijkt, dat Heyliger toen nog zijne Surinaamsche reis niet had aangevangen en inderdaad is hij ook eerst 9 Februari 1749 gegaan en was vóór 27 Juni van dat jaar terug ${ }^{5}$ ). In dien tijd valt het vergaan van het Compagniesschip de Catharina Galley kapitein Jan Pietersz., waarvan de constabel Adr. Pietersz. Schot en de matroos Joh. Dan. Boekenhoven den 20sten Februari van Bermudas op ons eiland weerkeerden. Jan Ellis was toen reeds van plan zich op Curaçao te gaan vestigen, waar hij eene plantage had, en is daarheen ook het volgend jaar met zijn gezin vertrokken. De kapiteinsplaats op St. Eustatius kwam daardoor vacant. Om hunnen hoogen ouderdom en hunne bedlegerigheid namen ook de raadsleden Joh. Markoe en Matthias Boreel Salomonsz. ontslag, waarop de commandeur uit hem aangeboden dubbeltallen Jan de Windt jun., Martin Dubrois Godet en Pieter Runnels koos. De jonge De Windt werd kapitein der burgerij, Abr. Simons Doncker luitenant, een andere Doncker vaandrager ${ }^{6}$ ).

$\S 23$. Onvermoeid gingen de notabelen op onze eilanden voort met hunne pogingen, om de Heeren tot aankoop van het Fransch gedeelte van St. Maarten te bewegen ${ }^{7}$ ). Het was ook inderdaad van overwegend belang. In 1746 drong Heyliger er op aan, omdat wij van het eiland zulk een prachtig handelscentrum van suiker

1) Joh. Heyliger Pzn. aan X, 27 Febr. 1751.

${ }^{2}$ ) Jan de Windt en Raden aan X, 21 Febr. 1754, port. no. 7, fol. 555. Missieven van X 24 Sept. 1753.

3) Boven, hoofdst. II, § 31 .

4) Jasper Ellis aan X, 15 Nov. 1747, port. no. 7, fol. 82. Wat nog geborgen was is later voor afbraak verkocht, aldaar fol. 386.

5) Port. no. 7, fol. 236, 252.

6) Jasper Ellis aan X, 25 Febr. 1749 en 5 Oct. 1750, port. no. 7, fol. 236, 237, 342.

Heyliger aan X, 27 Febr. 1751, boek 4, fol. 156, 157.

${ }^{7}$ ) Laatstelijk boven, $\S \S 2$ en 5 in fine. 
en katoen zouden kunnen maken ${ }^{1}$ ). Het volgend jaar betoogde Jan de Windt, dat het Fransche deel considerabel beter land was dan het Hollandsche, dat er wel 80 tot 100 suikerplantages op zouden kunnen komen, waarvan de minste nog 500 pesos waard zouden zijn. Ook de handel zou er door tot grooten bloei komen want alle natiën in Amerika handelden in vredestijd liever onder de ,duytse natie" dan onder hare eigene ${ }^{2}$ ). Heyliger, vernomen hebbende, dat er te Breda een vredescongres zou geopend worden, vroeg, smeekte bijkans, ,laat het $\mathrm{U}$ toch niet ontglippen, het zou zulk een kapitaal eiland worden" ${ }^{3}$ ). Men was overtuigd, dat alle bewoners van Anguilla er zich zouden vestigen en dat het eiland 15 à 20000 vaten suiker zou opbrengen. De commandeur deed de Heeren opmerken, dat zij dan ook hunne eigene aanwassende bevolking onder hun eigen gebied zouden kunnen houden, die thans naar de Deensche kolonies emigreerde. Hij herinnerde hen er aan, dat de Denen ook St. Kruis van het Fransche Hof voor 164000 Rd. gekocht hadden en er nu talrijke bloeiende plantages bezaten ${ }^{4}$ ). Weder het volgend jaar was het Abr. Heyliger Pzn. van St. Maarten die om den aankoop vroeg, nog naïvelijk overtuigd, dat de Heeren het belang ervan stellig zouden inzien, iets dat zij juist nu noch ooit deden ${ }^{5}$ ). Maar daardoor opmerkelijker wijze niet ontmoedigd was het in 1749 nu weder Joh. Heyliger Pzn., die berichtte dat eenige particuliere Engelsche heeren in onderhandeling waren met markies De Caylus en hem voor het Fransche gedeelte $7000 £$ geboden hadden. En die onderhandelingen waren blijkbaar verre gevorderd, want sedert den vrede van Aken (18 October 1748) had De Caylus den Franschen opgezetenen geraden naar St. Barthélemy te gaan, maar vestiging op St. Maarten tegengehouden ${ }^{6}$ ). Zou dit de Heeren opschrikken? De vice-commandeur van St. Maarten werkte nog eens op hun eigenbelang. Hij rekende hen vóór, dat het Fransche gedeelte wel $f 100.000$ (zegge honderd duizend gulden, voegt hij er nadrukkelijk bij) waard mocht zijn, dat zij dat bedrag door grondverkoop

1) Heyliger aan X, 15 Oct. 1746, port. no. 6, fol. 732 v., no. 7, fol. 5 .

$\left.{ }^{2}\right)$ Jan de Windt aan X 24 Jan. 1747, port. no. 6, fol. 784 r.

s) Heyliger aan X 13 Juni 1747, port. no. 7, fol. 5 v. Augustus 1746 waren te Breda de onderhandelingen begonnen, maar nog in het voorjaar 1747 was men weinig verder gekomen, Blok $a$. $w$. III, 433 vlg.

4) Heyliger aan X, 14 Aug. 1747, boek 3, fol. 698 v. Boven hoofdst. II, § 16.

5) Abr. Heyliger Pzn. aan X, 7 Jan. 1748, port. no. 7, fol. 87 r., 16 Maart 1748, boek 3 ,fol. 715 .

6) Joh. Heyliger aan X 27 Juni 1749, boek 3, fol. 750. Hij had 2 Dec. 1748 reeds op dien komenden vrede gezinspeeld, port. no. 7, fol. 227-229 (de bladzijden aan beide kanten genummerd). 


\section{NEDERLANDSCHE BOVENWINDSCHE EILANDEN}

aan planters er in zeven jaar uit zouden hebben en dat hun $2 \%$ van de producten immers aanmerkelijk stijgen zou. En zelfs dan nog, in door niets te verstoren deemoedigheid: „Ik stel dit in U.E.Gr.A. wijse en reijpe overweging, flatteerende mij dat U.E.Gr.A. niet qualijk nemen zult de vrijheyt die U.E.Gr.A. nederige dienaar neemt alsoo het enkel spruyt uit de groote Effectie (sic) tot behartigen U.E.Gr.A. interest" '1). Ja, schoon het haast ongeloofelijk is, toen hij eind November 1751 op dien brief van half Augustus 1749 nog geen antwoord had, gaf hij toch den moed niet op. Weder spiegelde hij den Heeren vóór, dat er voor al die plantages wel 8000 slaven noodig zouden blijken, die hij met winst voor U.E.Gr.A. aan de planters zou verkoopen, indien zij hem maar met slaven geliefden te fourneeren. Na zeven jaren zou het eiland dan zijn 20000 okshoofden suiker opbrengen, waarvan de $2 \%$ voor de Heeren geen onaanzienlijk bedrag zou vertegenwoordigen. Om van de katoen te zwijgen. St. Maarten kwam dan in de groote vaart en, wanneer het maar eenmaal in ééne hand was, dan zouden de opgezetenen ook met grooter vertrouwen van allerlei aanvatten, hetgeen zij thans niet durfden uit vrees dat zij, bij een oorlog, met den vijand op één eiland zouden zitten. Intusschen schatte hij thans den koopprijs reeds op $f 200.000^{2}$ ).

$\S 24$. In dezen stand der kwestie deed Ds. van Essen een zonderlingen stap. Wij laten het verhaal daarvan het best op het voorgaande volgen, ofschoon wij daardoor de grenzen van dit hoofdstuk, dat immers eindigen zal met den dood van commandeur Heyliger, overschrijden. Ofschoon wij zijne handeling niet voldoende kunnen verklaren, willen wij er toch op wijzen, dat hij gedrukt ging onder het gedrag zijner gemeentenaren en, als geboren Duitscher, vaak zijn oude vaderland gedacht. Sinds het vertrek van Mr. Bacot was er nog geen andere fiskaal benoemd en toch was een goed en verstandig rechter op het eiland zoo noodig. Volgens Ds. van Essen heerschte er een woest en heidensch christendom en Satan speelde er den meester door de oude, booze gewoonten, door allerlei excessen, ergernissen en impertinentiën. Alleen de hoop op beter tijden hield hem nog op St. Eustatius vast, want de meeste eilanders zouden liever zonder fiskaal, ,ja” zonder predikant als zotte Nabals in hunne dwaasheid smoren ${ }^{3}$ ). Hij was toen juist vijf jaren in dienst. Weder vijf jaren later was

\footnotetext{
1) Abr. Heyliger Pzn. aan X, 12 Aug. 1749, boek 4, fol. 2, 3 (ook hier thans de bladzijden aan beide kanten genummerd).

2) Abr. Heyliger Pzn. aan X, 11 Nov. 1751, boek 4, fol. 194-198.

3) Van Essen aan X, 20 Febr. 1747, port. no. 6, fol. 796 r.
} 
het vooral niet beter geworden. „Der tegenheden sat”, dacht hij nu ernstig over een anderen werkkring, maar wilde toch gaarne, hoe gevaarlijk en moeielijk de reis ook zijn mocht, van te voren eens overkomen om met de Heeren te spreken ${ }^{1}$ ). In zulk eene stemming doet men licht onberaden dingen.

Hij schreef dan aan eenen niet nader aangeduiden Heer van het Hof van Z.M. den Koning van Pruissen d.d. St. Eustatius 18 Juni 1755 als volgt $\left.{ }^{2}\right)$ :

„Sijn Excellence mijn genadige Heere! Aengesien Sijn Maiesteit den Koning van Pruyssen garne landt en zeevaardt ook in de West Indiën mogte hebben, zoo hebbe ik niet mankeeren konnen daervan eenige oplichtinge aan Sijn Excellence als een groote favorite van Sijn Maiesteit alleronderdaenigst en seer welmeenende te geven; namelijk dat de koning van Frankrijk en wel insonderheid in dese omstandigheden van tijden mogelijk door goede werktuigen daertoe was over te haalen om Sijn Eylandt St. Maarten genoemt te verkoopen en dat door niemandt beeter konde ondernoomen worden als door Sijne Maiesteit den koning van Pruyssen, waarvoor het ook het allerbeste soude weesen in dese eene rupture drijgende Tijden; konnende alsdan ook dienen tot een schuylplaats voor veelen.

„Doch dit moet ik er bijvoegen dat alhier wel kooplieden daartoe sich souden aengeven bijaldien sij maar mogten hebben de rechte vermogende adressen daertoe aan het Fransche hof en alsdan wanneer het daartoe komen mogte een Beschutheer en die alsdan het gekogde Eylandt met groot voordeel wederom souden bij het morgental verkoopen en zoo was die voordeel alsdan voor haar selven, ik kan voor vast versekeren dat er veel meer goede koopers als er landt is sich souden aangeven. De gouverneur op het Hollandsch quartier van St. Maarten de heer Abraham Heyliger heeft het al eenigen tijt geleden laten afmeten en die sou ook het beste in staat wesen om hetselve te taxeeren".

Er volgt nu eene beschrijving van het Fransche gedeelte, onbe-

1) Van Essen aan X, 27 Maart 1752, port. no. 7, fol. 465

2) Origineel, boek 4, fol, 483-486. In de inhoudsopgave vóór in boek 4 staat: „Uit Zeeland ingekomen bij de vergadering van Tienen, geschreven aan een Heer van het Hof van Z. M. den Koning van Pruyssen". Aan wien had Van Essen den brief gezonden? Was hij onderschept? En hoe kwam commandeur Jan de Windt aan de nader te noemen copie? Wat den geadresseerde aangaat, mijn vriend, de heer W. J. J. C. Bijleveld, wees mij op Casimir, Graf zu Kolbe von Wartenberg, geb. 6 Mei 1699, generaal der cavallerie, groot gunsteling van Frederik den Groote, gest. 2 Oct. 1772, dien van Essen in Kleef of Meurs kan hebben leeren kennen. Hij was de zoon van Johann Casimir zu Kolbe, 1sten graaf von Wartenburg, getrouwd met Catharina Riekers, de officieele bijzit van Pruissens eersten koning. Zie Nieuwe Cour. van 31 Jan. 1 Febr. 1928 en voor de genealogie Maandblad Ned. Leeuw, 1928, kol. 102-106. 


\section{NEDERLANDSCHE BOVENWINDSCHE EILANDEN}

volkt, als een der beste eilanden van West Indië vooral voor suikerriet, veel gezonder dan St. Kruis. En dan: „Ik hadde voorgenomen een waterschildpad aan S. M. mijnen allergenadigsten koning over te senden met een vertrokken schip sijnde 6 May maar in twijvel sijnde of deselve wel levendig van Amsterdam naar Berlijn hadde konnen transporteert worden, zoo hebbe ik sulks uytgestelt Zulk een schildpadt wordt voor een present gehouden kostelijk om te eeten. Alleronderdaanigst verzoek aan S. Exc. mij aanbevelingsbrief bij S. M. kon besorgen tot mijn securiteit tegen alle vijandelijkheden in case van oorlog, in duplo in 't Fransch want wij souden alsdan hier maar komen te sitten als een vogel op een $\left.\operatorname{tak}^{1}\right)$. En zoo konde het met meer securiteit met twee schepen mij van Amsterdam verder worden toegesonden."

$\mathrm{Na}$ enkele mededeelingen over zichzelven, reeds vroeger vermeld ${ }^{2}$ ), eindigt Ds. van Essen: „Mocht ik enigen ingang getroffen hebben dan garne bericht adres aan mijn neef Ernst van Essen, predikant te Amsterdam."

De heeren gecommitteerden wegens de presidentale Kamer te Amsterdam, aanstonds door den commandeur Jan de Windt ingelicht, die zelfs reeds copie van Van Essens brief kon insluiten ${ }^{3}$ ), waren over Van Essens daad ten uiterste verwonderd. Zij schreven hem, dat het hem niet onbekend kon zijn, dat niet alleen de tegenwoordige commandeur, maar ook zijn voorganger wijlen Heyliger meenigmaal ditzelfde hadden aangeraden. Zij vonden 's mans gedrag in dezen te minder verschoonbaar nadien het hem, in actueelen dienst der Compagnie zijnde, in geenen deele paste zich met propositiën aan vreemde vorsten op te houden buiten kennis zijner meesters. Hij zou wel doen zich voortaan alleen op zijn predikantsambt toe te leggen en zich van publiekeaangelegenheden te onthouden. Aldus hebben zij hem over zijne onbehoorlijke en ongepermitteerde correspondentie serieuselijk gereprocheerd en hem in het vervolg een betamelijker en met de interessen zijner heeren en meesters meer overeenkomend gedrag gerecommandeerd $\left.{ }^{4}\right)$. Men ziet, hoe snel zij er bij waren toen zij hun gezag "gelaedeerd" vonden ${ }^{5}$ ). Zelven deden zij niets voor den

1) Deze uitdrukking gebruikt ds. van Essen ook in een brief aan classis van 15 Febr. 1755 en reeds vroeger 20 Febr. 1742.

2) Boven, hoofdst. V, § 3, I, 1.

3) Jan de Windt aan X, 28 Juni 1755, port. no. 7, fol. 692.

4) Kamer Amsterdam aan Van Essen, 9 Sept. 1755, geteekend door Pieter van den Broeck en Adriaan Temminck. Van dezen brief deden zij mededeeling in de vergadering van 18 Aug. 1756, waar ook de missive van De Windt van 28 Juni 1755 ter tafel was, Resolutiën van X Mercurii 18 Aug. 1756, fol. 120.

5) Toen de assistent Theod. de Vos het waagde, na den dood van commandant An- 
aankoop. Intusschen blijft de stap van Ds. van Essen vreemd. Gevolgen heeft hij niet gehad ${ }^{1}$ ).

$\S 25$. Hebben wij met dit relaas de grenzen van ons hoofdstuk voor een oogenblik moeten overschrijden, wij keeren thans op onzen weg terug, om nog van delaatste maanden van commandeur Heyligers leven eenig bericht te geven, die werden ingenomen door een schandelijk geval van zeeroof, dat de Raad van St. Eustatius te berechten kreeg. Op de kust van N. Carolina had een orkaan een aantal Spaansche galjoenen overvallen, die op weg waren naar Europa. Vier ervan en één oorlogsschip geraakten daardoor ,,in onmacht”, een schip werd zelfs over de banken op het strand geslagen, de Neustra Señora de Guadeloupe alias La Nympha, alias La Augusta, kapitein-eigenaar Don Juan Manuel de Bonilla. De Spanjaarden huurden toen Engelsche barken om de lading te lossen o.a. de Seaflower schipper Zebulon Wade woonachtig in Boston. Volgens zijn, later blijkend valsch, getuigenis en dat van zijn passagier Owen Lloyd waren, toen de bark volgeladen was, drie schelmen aan boord gekomen, kapitein Blackstock een éénoogig man, kapitein Thomas Dames en James Mac Clear, die hem en Lloyd in de kajuit hadden opgesloten en daarna de bark onder zeil gebracht, tevergeefs door Spaansche roeibooten achtervolgd. De buit bestond uit 55 kisten ieder met 3000 Spaansche dollars, 2 koffers met zilverwerk, 118 zakken cochenille, 68 gelooide en 317 ruwe huiden, indigo en 140 zakken tabak. Naar St. Eustatius koers zettend waren zij op het onbewoonde Noormans eilandje aan wal gegaan, waar zij den buit gedeeld, het grootste deel contanten begraven en de rest meêgenomen hadden. Eenige dagen daarna kwamen Wade en Lloyd, die hun eigen bark naar St. Thomas hadden gebracht, haar daar onder stuurman Abr. Prichard en twee matrozen gelaten en vervolgens van de geroofde penningen op St. Kruis eene andere bark gekocht hadden, op St. Eustatius aan. Heyliger, intusschen ingelicht, liet hen gevangen nemen en het schip lossen. Aan kontanten vond men 5702 pes., een zilveren kop en 3 oude zilveren lepels. Lloyd, zich willende schoonwasschen, bood aan om de op Noormans eiland

dries Ravené, den konstabel Lespier aan te bevelen, hebben de Heeren hem over deze vermetelheid en hardiesse ernstig berispt: iemand van zóó lagen rang en geringe qualiteit mocht hún geen voordracht doen! En commandeur De Windt heeft hem dan ook met eene „scherpe vermaning” ernstig moeten onderhouden over zijne „onbezonnen en arrogante recommandatie". Th. J. de Vos aan X, 17 Juni 1759, boek 4, fol. 625. Missiven van $\mathrm{X}, 16$ Mei 1760 . Jan de Windt aan X, 10 Nov. 1760 , boek 4, fol. 630 .

$\left.{ }^{1}\right)$ De koning stond in 1755 vóór den Zevenjarigen oorlog, maar ook overigens beschouwde men in Pruisen koloniale politiek nog als „chimere”, Colenbrander, Koloniale Geschied. I, 379. 


\section{NEDERLANDSCHE BOVENWINDSCHE EILANDEN}

begraven schatten aan te wijzen. De commandeur charterde toen (een gouvernementsvaartuig, wij zeiden het al vaak, was er niet) de bark Don Philip, schipper John Farrow voor 400 pes. waarmede Lloyd in ijzer en banden, onder toezicht van den commandant Andries Ravené zelven en twee der beste soldaten 28 November 1750 vertrok. Bij Saba vonden zij toen in een boot nog twee zeeroovers, den genoemden Abr. Prichard en James Mac Mahan, die in het bezit bleken van $11167^{1} / 2$ pes. en 478 oncen oud zilverwerk. Op Noormanseiland daarentegen bleken de vindplaatsen opgegraven door, zooals later aan den dag kwam, menschen van Tortola, terwijl op den grond $21^{1 / 2}$ pes. verspreid lagen. Op ons eiland 9 December teruggekeerd, zagen de vier gevangenen kans (zooals immers op St. Eustatius gebruikelijk was) ${ }^{1}$ ) den wachthoudenden korporaal Jan Jansen met de soldaten Jan Schröder van Kochem a/d Moezel en Jan Frederiks van Stoutenach om te koopen en voorts met hen naar St. Eustatius te ontkomen.

De Raad kon dus slechts bij verstek, na driemalige indaging, vonnissen. Hij veroordeelde Wade, Lloyd, James MacMahan en stuurman Richard tot de galg en om te blijven hangen tot de lucht hen verteerd had; den korporaal en de beide soldaten om te worden geharkebuseerd en onder de galg begraven. De bark werd verkocht, $2 / 3$ ten profijte van den lande, $1 / 3$ voor den commandeur, eischer R.O. De Engelsche generaal Fleming was intusschen naar Tortola gegaan, maar had van het gestolene weinig kunnen machtig worden, schoon hij den vrijwilligen aanbrengers $1 / 3$ beloofd had. De cochenille en de indigo waren in de bark op St. Thomas aangehouden en daar publiek verkocht. Inmiddels had de kapitein-eigenaar van het geplunderde schip een zaakgelastigde, John Watson van Suffolk Town in Virginië, Augustus 1751 naar St. Eustatius gezonden om het geld van de goederen op te vorderen, een eisch dien de Raad hem ontzegde, omdat er nog geen orders uit patria waren. Het volgend jaar kwam het bevel, om al het zilver en de contanten, die Heyliger in de consignatiekas des eilands geborgen had aan Don Juan over te geven, gelijk ook geschiedde. John Watson bedankte voor de uitstekende ontvangst en ondervonden medewerking. Het geld en de goederen maakte de commandeur, na aftrek der gemaakte onkosten, over aan Messrs. Robert en John Lidderdale te Londen ${ }^{2}$ ).

1) En op St. Maarten. „Van die zes militairen weigerden twee dienst, drie hebben zich door arrestanten laten omkoopen om te deserteeren....", Abr. Heyliger Pzn. aan X, 28 Mei 1759, boek 4, fol. 605. En op de betaalpost vindt men telkens: „uitbetaald tot .... op heden gedisserteert....", b.v. boek 4, fol. 569, 4 .

2) Comm. en Raden aan X, 27 Febr. 1751, boek 4, fol. 87-90, 157, 159-162. Dez. 
Wat die onkosten aangaat, Heyliger had gevraagd van het te verantwoorden bedrag 3800 pes. te mogen afhouden voor zijn bark de Jonge Elias, die met vier van zijne beste slaven, 14 maanden geleden, van de reede van St. Eustatius naar Porto Rico was „weggeloopen" en daar werd vastgehouden onder voorwendsel o.a. dat die negers van onder de ketters wegkwamen om (R.K.) christenen te worden. Hij rekende de bark op 2000, eene lading kalk op 200, de slaven, ofschoon zij hem ieder 500 gekost hadden, op 1600 , tezamen 3800 pes. Dit wegloopen van slaven naar de Spaansche eilanden gebeurde vaak, en altijd hielp men hen daar voort onder voorgeven dat men hen daar christenen maakte, ofschoon de Spaansche ambassadeur in Den Haag, de markies Del Puerto dat ontkende ${ }^{1}$ ). De Staten protesteerden dan wel maar zonder veel hoop, ,daar diergelijke seer gegronde klachten zelden van eenige uytwerking geweest zijn bij den Hoff van Spanjen" ${ }^{2}$ ).

$\S 26$. Commandeur Heyliger had zich 26 October 1752 met „Mevrouw zijne beminde” en met den secretaris van St. Maarten, Albert van Heyningen, voor zaken naar St. Kruis begeven, was daar „met impotentie bevangen” en daarom 13 November op reis naar huis gegaan. Door storm overvallen, deed het schip Engelsch Spanish Town (Virgin Gorda) aan, waar de commandeur Dinsdag morgen 21 November 1752 tusschen 5 en 6 uur overleed, „naardien het den albestierenden Jehova behaagde hem uit dit droevig jammerdal in sijne eeuwige vreugde over te haalen". In hem verloren de opgezetenen eenen goeden gouverneur, de Heeren een trouwen dienaar ${ }^{3}$ ). Naar het opengevallen ambt dong vooreerst Jan de Windt jun. met de gewone, eindelooze en slaafsche strijkages. De Raad voegde er eene warme aanbeveling bij: hij was

23 Aug. 1751 aldaar, fol. 183-185. Copie auth. wit register der sententien, 28 Nov. 1750, aldaar fol. 91, 92. Interrogatoriën, van Zebulon Wade, aldaar fol. 93-98; van Lloyd aldaar, fol. 99-103; van denz., na zijn terugkeer van Noormanseiland aldaar fol. 104, 105; van Thomas Hodson, scheepsjongen, aldaar fol. 107, 108. Eisch tegen Wade, Lloyd, Mac Mahon en Prichard aldaar fol. 140-152 en 163-174 (dupl.); tegen korporaal en soldaten aldaar fol, 153, 154 en 175, 176 (dupl.). Indagingen op 31 Januari, 7 en 14 Februari aldaar, fol. 155. Humble petition of John Watson of Suffolk Town in the colony of Virginia, marchant attorny lawfully constituted of Don Juan Manuel de Bodilla 11 Juni 1751 aldaar fol. 186-190. John Watson aan Heyliger 24 Juni 1751, port. no. 7 , fol. 476 .

1) Heyliger aan X 27 Febr. 1751, boek 4, fol. 90, 159-162. Dez. 8 Juli 1752, port. no. 7 fol. $460,461,470,471$.

$\left.{ }^{2}\right)$ Kamer Amst. aan Heyliger 7 Sept. 1751, 31 Dec. 1751, 14 Maart 1752, 342 W. I. C. 475 .

3) Jan de Windt aan X, 28 Nov. 1752, port. no. 7, fol. 480-482; boek 4, fol. 351 353. Alb. van Heyningen d.d. St. Maarten 30 Nov. 1752, aldaar fol. 357. Abr. Heyli ger Pzn., d.d. St. Maarten, 4 Dec. 1752, aldaar fol. 354, 355. Mevrouw Heyliger geb. Judith Simonsz. Doncker, zou 12 April 1755, 42 jaar oud, hertrouwen met Robert Stuwart van Antrim (Ierland), Trouwboek St. Eust. no. 252 op datum R. A. 


\section{NEDERLANDSCHE BOVENWINDSCHE EILANDEN}

vigilant, bekwaam en dapper, hij zou recht en justitie handhaven en rust en vrede bevorderen; allen zouden over zijne benoeming ten uiterste tevreden zijn, maar onderwierpen zich voor het overige op het ootmoedigst aan H.E.Gr.A. wijsheid ${ }^{1}$ ). Een paar maanden later, toen hij iets te schrijven had over den inkoop van vleesch, vroeg hij nog eens om het ambt, in dezen trant schrijvend: „verder dient onder reverentie en nedrige submissie U.E.Gr.A. voor te dragen of U.E.Gr.A. zouden gelieven het proviant vlijs behaaglijk te zijn alhier in te koopen als komende mij onder approbatie van U.E.Gr.A. voor, hetzelve hier goetkooper kan ingekocht werden als deselve U.E.Gr.A. in Europa komt te staan, gemerkt men een Iersch vat vlijs hier krijgt voor $8-9-91 / 2$ pes." Daarop volgt dan nog eens de sollicitatie ${ }^{2}$ ).

Ook Abr. Heyliger Pzn. vroeg, en hij drong te ernstiger op de benoeming aan, omdat hij als voogd over zijns broeders kinderen en voor de zaken zijner hoogbejaarde moeder telkens op S. Eustatius zijn moest. En zoozeer hield men zich op St. Maarten van die benoeming verzekerd, dat Albert van Heyningen alvast vroeg om in dat geval vice-commandeur te mogen worden $\left.{ }^{3}\right)$. Ten slotte waagde de secretaris van St. Eustatius, Joh. de Graaf, „met diepste onderdanigheid en soumissie (zijn) persoon te recommandeeren, soo 't U.E.Gr.A. behaagen mogt (hem) met het gouvernement te honoreeren. Heb thans de tweede rang in 't politieke wezen op dit eylandt" "4). Intusschen benoemden Bewindhebberen bij missive van 24 September 1753 Jan de Windt jun. Hij zou 22 jaar het gezag voeren.

1) Jan de Windt 28 Nov. 1752 als boven. De Raad aan X, 6 Dec. 1752, port. no. 7 fol. 483,484 .

2) Jan de Windt aan X, 16 Febr. 1753, port. no. 7, fol. 487-489. Voorts nog 8 April 20 Juni en 2 Aug. 1753, aldaar fol. 457, 513, 516.

3) Abr. Heyliger Pzn. 4 Dec. 1752 als boven. Alb. van Heyningen 30 Nov. 1752 als boven.

4) Joh. de Graaf aan X, .. Dec. 1752, boek 4, fol. 359-361. 